\title{
Expression of the functional carbohydrate-binding module (CBM) of human laforin
}

\author{
Susana Moreira ${ }^{\mathrm{a}, 1}$, Pedro Castanheira ${ }^{\mathrm{b}, 1}$, Margarida Casal ${ }^{\mathrm{c}}$, Carlos Faro ${ }^{\mathrm{b}}$, Miguel Gama ${ }^{\mathrm{a}, *}$ \\ ${ }^{a}$ IBB - Institute for Biotechnology and Bioengineering, Centre of Biological Engineering, Universidade do Minho, Campus de Gualtar, 4710-057 Braga, Portugal \\ ${ }^{\mathrm{b}}$ Biocant - Molecular Biotechnology Unit - Parque Tecnológico de Cantanhede, Núcleo 4 Lote 3, 3060-197 Cantanhede, Portugal \\ ${ }^{\mathrm{c}}$ CBMA - Centre of Molecular and Environmental Biology, Department of Biology, Universidade do Minho, Campus de Gualtar, 4710-057 Braga, Portugal
}

\section{A R T I C L E I N F O}

\section{Article history:}

Received 22 April 2010

and in revised form 23 June 2010

Available online 1 July 2010

\section{Keywords:}

Laforin

Carbohydrate-binding module

RGD

Inclusion bodies

\begin{abstract}
A B S T R A C T
Laforin is a human protein associated with the glycogen metabolism, composed of two structurally and functionally independent domains: a phosphatase catalytic domain and a substrate-binding module with glycogen and starch affinity. The main goal of this work is the development of a methodology for the expression of the so far poorly characterized carbohydrate-binding module (CBM) of laforin, allowing its study and development of biomedical applications. The laforin's CBM sequence was originally cloned by PCR from a human muscle cDNA library. The recombinant protein, containing laforin's CBM fused to an Arg-Gly-Asp sequence (RGD), was cloned and expressed using vector pET29a and recovered as inclusion bodies (IBs). Refolding of the IBs allowed the purification of soluble, dimeric and functional protein, according to adsorption assays using starch and glycogen. Several other experimental approaches, using both bacteria and yeast, were unsuccessfully tested, pointing towards the difficulties in producing the heterologous protein. Indeed, this is the first work reporting the production of the functional CBM from human laforin.
\end{abstract}

(c) 2010 Elsevier Inc. All rights reserved.

\section{Introduction}

Laforin is a human dual specific phosphatase (DSP), ${ }^{2}$ coded by the EPM2A gene, involved in the glycogen metabolism and implicated with a human disorder - Lafora disease (LD), a progressive myoclonus epilepsy [1-3].

Laforin presents the modular structure frequently found in the CAZymes (enzymes that act on carbohydrates) [4], containing a carbohydrate-binding module (CBM) at the $\mathrm{N}$-terminus connected by a linker to the $\mathrm{C}$-terminal catalytic module [2]. Since each module performs and folds independently, several CBM applications have been described, namely its use as purification and solubilization tags in fusion proteins [5]. CBMs are classified according to the sequence homology, the laforin's CBM being assigned to family 20 (http://www.cazy.org/). The three-dimensional (3D) structure of laforin (including its CBM domain) is still unknown. Furthermore, recombinant laforin has been reported to aggregate easily, which

\footnotetext{
* Corresponding author.

E-mail address: fmgama@deb.uminho.pt (M. Gama).

1 Both authors contributed equally to this work.

2 Abbreviations used: CBM, carbohydrate-binding module; RGD, Arg-Gly-Asp sequence; IBs, inclusion bodies; DSP, dual specific phosphatase; LD, Lafora disease; 3D, three-dimensional; LBs, Lafora Bodies; ECM, extra-cellular matrix; PLL poly-L-lysine; RGD, Arg-Gly-Asp; IMAC, immobilized metal ion affinity chromatography; DLS, dynamic light scattering; CAZy, carbohydrate-active enZymes database; IPTG, isopropyl $\beta$-D-1-thiogalactopyranoside.
}

explains the difficulty in obtaining enough protein for 3D structure analyses [6].

It has been shown that this CBM binds complex carbohydrates in vivo and in vitro [2], and the DSP motif can hydrolyze phosphotyrosine and phosphoserine/threonine substrates in vitro $[1,6]$. Laforin is the single human phosphatase containing a CBM and has been shown to liberate phosphate from the complex carbohydrate amylopectin, whereas other phosphatases lack this activity [7]. The main function of CBMs is to target the enzyme to the substrate, increasing its activity, particularly in the case of insoluble carbohydrates [5]. Besides binding laforin to glycogen, it was also demonstrated that this CBM also drives the enzyme to Lafora Bodies (LBs), dense aggregates of polyglucosan fibrils structurally similar to starch [8]. In addition, the CBM of laforin fused to the DSP of vaccinia H1-related phosphatase still binds amylopectin [7], thus the laforin-CBM remains functional when fused with other peptides. In this context, bioactive peptides may be adsorbed to biomaterials made of starch, through the fusion with CBM, in order to achieve their functionalization for biomedical applications.

Among the bioactive molecules used to functionalize biomaterials, proteins of the extra-cellular matrix (ECM), poly-L-lysine (PLL) and a natural adhesive protein extracted from mussel (MAP) [9] have been successfully applied in promoting cell adhesion and proliferation [10-13]. The Arg-Gly-Asp (RGD) motif - found in ECM and blood proteins, such as fibronectin, vitronectin, osteopontin, collagens, thrombospondin, fibrinogen, and von Willebrand factor - was described as the major functional group responsible for 
cellular adhesion $[9,14]$. Several strategies to functionalize materials, through the immobilization of RGD on the material surface, have been developed [15-17]. However, most of these strategies involve the activation of either the polymer or the RGD-containing sequence, to allow for the covalent binding. On the other hand, it has been described that the RGD bioactivity can be conserved in fusion proteins $[18,19]$; therefore, in this work, the RGD was fused to the laforin's CBM in order to produce a recombinant protein for functionalization of starch material, by the adsorption of the protein through CBM affinity. Indeed, several CBMs were already used for protein targeting [20,21], including a CBM from family 20 with starch affinity, which was fused with RGD sequence to functionalize starch-based materials [22]. However, the utilization of a human protein seems a better choice when in vivo applications are envisioned.

Although laforin has been cloned and purified, the application of the laforin-CBM as a target partner has never been described. Therefore, in this study, a strategy was developed to express, purify and functionally characterize a recombinant protein containing the human laforin-CBM fused to RGD tripeptide in Escherichia coli.

\section{Material and methods}

\section{Reagents and strains}

All reagents used were laboratory grade from Sigma-Aldrich (St. Louis, USA), unless stated otherwise. E. coli strain XL1 Blue, from Stratagene (Carlsbad, CA, USA) was used as bacterial host for DNA cloning. For protein expression E. coli BL21 (DE3) strain and the T7 plasmids pET29a and pET25b (+) were purchased from Novagen (Madison, USA) and pGEX4-T1 from GE Healthcare. The oligonucleotides presented in Table 1 were purchased from MWG Biotech (Germany). Restriction enzymes and T4 DNA ligase were purchased from Roche Diagnostics GmbH (Penzberg, Germany). Pfu DNA polymerase used was from Stratagene, and the MasterAmp 10X PCR Enhancer from EPICENTRE Biotechnologies. Thrombin protease and isopropyl $\beta$-D-1-thiogalactopyranoside (IPTG) were from GE Healthcare. The theoretical molecular masses of the recombinant proteins were calculated using the Compute $\mathrm{pI} /$ Mw application from ExPASy Proteomics Server (http://www.exp asy.ch/tools).

\section{Gene cloning}

The DNA coding sequence of the glycogen-binding module of laforin was amplified using a human muscle cDNA library (CLONTECH). This sequence was used as template, to clone the CBM coding sequences by PCR with the RGD coding sequence being introduced in the reverse primer. The PCR reactions were performed using Pfu DNA polymerase (2.5 U), $0.5 \mathrm{mM}$ of each primer (forward and reverse according to Table 1), $1.2 \mathrm{mM} \mathrm{MgSO}_{4}$, $0.24 \mathrm{mM}$ dNTP, 1.2X enzyme buffer, and 1.2X of PCR enhancer solution. PCR conditions were: denaturation at $95^{\circ} \mathrm{C}$, annealing at $56{ }^{\circ} \mathrm{C}$ and extension at $72{ }^{\circ} \mathrm{C}$, all steps for $45 \mathrm{~s}$ (this cycle was repeated 30 times).
The DNA coding sequences were cloned in different expression system, allowing for the fusion of recombinant proteins with a hexa-histidine tag (6xHis) on the C-terminal (pET expression systems) or GST on the N terminal (pGEX expression system), for purification. The E. coli XL1 Blue was used as cloning strain and expression was carried out in E. coli BL21 (DE3), E. coli BL21 star, Origami or Tuner. Cell carrying the non-modified plasmid (without DNA coding sequence) was used as negative control.

The integrity of cloned PCR products was verified by DNA sequencing [23] using ABI PRISM310 Genetic Analyzer.

\section{Recombinant His-tagged protein expression and purification}

The non-modified pET25, pET25-CBM or pET25-CBM-RGD was used to transform E. coli expression host (BL21 DE3, Origami, Tuner). Cells were cultivated in LB medium at $30^{\circ} \mathrm{C}$ until $\mathrm{OD}_{600}$ reached 0.4 and induced by adding IPTG to a final concentration of $0.1 \mathrm{mM}$ for $16 \mathrm{~h}$. At the end of fermentation, cells were harvested and periplasmic proteins recovered using the previously described protocol [24].

To recover the cytoplasmatic proteins, cells were lysed in buffer containing $50 \mathrm{mM}$ Tris- $\mathrm{HCl}$, pH 7.4, $300 \mathrm{mM} \mathrm{NaCl}, 0.1 \%$-mercaptoethanol, $1 \mathrm{mM}$ PMSF. After sonication, $0.6 \mathrm{M}$ arginine and $1 \%$ CHAPS (3-[(3-Cholamidopropyl) dimethylammonio]-1-propanesulfonate) were added to the lysate. The mixture was incubated at $4{ }^{\circ} \mathrm{C}$, with gentle agitation for $16 \mathrm{~h}$ and centrifuged $(30 \mathrm{~min}$, $15000 \mathrm{rpm}, 4^{\circ} \mathrm{C}$ ). The recombinant protein in the supernatant was purified by immobilized metal ion affinity chromatography (IMAC), using $5 \mathrm{ml}$ Nickel His-Trap columns (GE Healthcare) according to the manufacturer's instructions.

\section{Expression and purification of GST-tagged recombinant protein}

Cells transformed with expression vectors pGEX-CBM, pGEXCBM-RGD or non-modified pGEX were grown at $37^{\circ} \mathrm{C}$ in LB medium until $\mathrm{OD}_{600}$ reached 0.7 . At this point temperature was lowered to $20^{\circ} \mathrm{C}$ and after $1 \mathrm{~h}$ protein expression was induced by IPTG addition (0.1 mM final concentration). twenty hours later, cells were harvested, resuspended in lysis buffer $(10 \mathrm{mM}$ Tris- $\mathrm{HCl}, 150 \mathrm{mM} \mathrm{NaCl}$, $1 \mathrm{mM}$ EDTA, pH 8.0) and incubated with deoxyribonuclease I $(100 \mu \mathrm{g} / \mathrm{ml})$ and $\mathrm{MgCl}_{2}(100 \mathrm{mM})$. After DNA digestion, $100 \mu \mathrm{l}$ of Triton $\mathrm{X}-100$ was added and the supernatant incubated with Glutathione-Sepharose CL 4B (GE Healthcare). Protein elution was performed using Tris buffer ( $50 \mathrm{mM}$ Tris- $\mathrm{HCl}$, pH 8.0) containing $10 \mathrm{mM}$ reduced glutathione. Recombinant protein was treated with thrombin protease ( $10 \mathrm{U} / \mathrm{mg}$ of recombinant protein), according to the manufacturer's instructions (GE Healthcare).

Recombinant protein expression in inclusion bodies (IBs), refolding, and purification

The culture of $E$. coli BL21 star (Invitrogen) transformed with pET29a-CBM-RGD expression vector was grown in $1 \mathrm{~L}$ LB medium with $30 \mu \mathrm{g} / \mathrm{ml}$ kanamycin at $37^{\circ} \mathrm{C}, 185 \mathrm{rpm}$ in New Brunswick Innova $44 \mathrm{R}$ incubator shakers. The expression of CBM-RGD protein

Table 1

Primers utilized to amplify the coding sequence in the different expression systems. The sequences recognized by the restriction enzymes are in bold. The RGD coding sequence is underlined.

\begin{tabular}{lll}
\hline Plasmid & Primer $\left(5^{\prime} \rightarrow 3^{\prime}\right)$ & Restriction enzyme \\
\hline pET25b and pET29a & For CATGCCATGGGGATGCGCTTCCGCTTTGGGG & Ncol \\
& Rev GGAATTCATGGCTTGGTGGCCTGC & EcoRI \\
& Rev CCGCTCGAGATCACCTCTCATGGTTGGTGGCCTGC & Xhol \\
pGEX 4T1 & For GGATCCATGCGCTTCCGCTTTGGGG & BamHI \\
& Rev GGAATTCATGGCTTGGTGGCCTGC & EcoRI \\
& Rev CCGCTCGAGATCACCTCTCATGGTTGGTGGCCTGC & Xhol \\
\hline
\end{tabular}


was induced by the addition of IPTG into the culture medium at mid-log phase $\left(\mathrm{OD}_{600} 0.6\right)$ to $0.5 \mathrm{mM}$ final concentration. After $3 \mathrm{~h}, 3.74 \mathrm{~g}$ of cells (wet weight) were harvested, resuspended in $50 \mathrm{ml}$ of buffer A ( $50 \mathrm{mM}$ Tris- $\mathrm{HCl}, 50 \mathrm{mM} \mathrm{NaCl}, \mathrm{pH} 7.4$ ), and lysed by adding lysozyme $(100 \mu \mathrm{g} / \mathrm{ml})$. After freezing and thawing, deoxyribonuclease I $(100 \mu \mathrm{g} / \mathrm{ml})$ and $\mathrm{MgCl}_{2}(100 \mathrm{mM})$ were added and incubated at $4{ }^{\circ} \mathrm{C}$ for $1 \mathrm{~h}$. The IBs were then washed for $3 \mathrm{~h}$ with $1 \mathrm{~L}$ of buffer $\mathrm{A}$, centrifuged (at $10000 \mathrm{~g}$ for $20 \mathrm{~min}$ at $4{ }^{\circ} \mathrm{C}$ ), and washed again for $3 \mathrm{~h}$ with $1 \mathrm{~L}$ of buffer A containing $0.1 \%$ Triton X-100 (v/v). Upon centrifugation (10 $000 \mathrm{~g}$ for $20 \mathrm{~min}$ at $\left.4{ }^{\circ} \mathrm{C}\right)$, purified IBs were dissolved in $50 \mathrm{ml}$ of $8 \mathrm{M}$ urea buffer ( $8 \mathrm{M}$ urea, $0.1 \mathrm{M}$ Tris, $1 \mathrm{mM}$ glycine, $1 \mathrm{mM}$ EDTA, pH 10.5 ) with $100 \mathrm{mM} \beta-$ mercaptoethanol and then the protein was refolded by rapid dilution (20-fold) at room temperature into $1 \mathrm{~L}$ of $20 \mathrm{mM}$ Tris, $0.5 \mathrm{mM}$ oxidized/1.25 mM reduced glutathione, $0.5 \mathrm{mM}$ DTT without prior $\mathrm{pH}$ adjustment; the $\mathrm{pH}$ was then slowly (over a $2 \mathrm{~h}$ period) adjusted to 8.0 with $6 \mathrm{M} \mathrm{HCl}$ and the solution was kept at cold room until purification.

After 3-4 days to a week period the refolded CBM-RGD solution was first concentrated by tangential flow ultrafiltration (Pellicon 2; Millipore) to approximately $150 \mathrm{ml}$, followed by a $\mathrm{N}_{2}$ pressurized stirred cell concentrator (Amicon 8200 - Millipore) to $12-15 \mathrm{ml}$. After ultracentrifugation to clarify the solution $(100000 \mathrm{~g}$, $20 \mathrm{~min}, 4^{\circ} \mathrm{C}$ ), the protein was applied to a $320-330 \mathrm{ml}$ bed volume HiLoad 26/60 Superdex 200 prep grade column (Amersham) preequilibrated at room temperature with $20 \mathrm{mM}$ Tris, $0.4 \mathrm{M}$ urea, $\mathrm{pH} 8.0$ at $2.0 \mathrm{ml} / \mathrm{min}$. Urea was kept in the purification buffer in order to prevent the protein aggregation [25].

The fractions eluted between 150 and $200 \mathrm{ml}$, corresponding to non-aggregated forms of recombinant protein, were then combined and further purified by ion exchange chromatography on a $1 \mathrm{ml}$ Mono Q HR 5/5 column (GE Healthcare) using the same buffer as for the Superdex 200 chromatographic experiment with a linear gradient of $\mathrm{NaCl}(0-0.5-1 \mathrm{M})$ at $0.75 \mathrm{ml} / \mathrm{min}$.

\section{Recombinant protein analysis}

Recombinant protein was analyzed either by Coomassie stained $12 \%$ SDS-PAGE (sodium dodecyl sulfate-polyacrylamide gel electrophoresis) and 10\% native PAGE, which was used to evaluate protein aggregation. For MW determination the protein was analyzed by gel filtration chromatography on a $24 \mathrm{ml}$ bed volume Superdex 200 10/300 GL column (GE Healthcare) equilibrated in $20 \mathrm{mM}$ Tris- $\mathrm{HCl}, 150 \mathrm{mM} \mathrm{NaCl}, \mathrm{pH} 8.0$ buffer, at $0.4 \mathrm{ml} / \mathrm{min}$. The molecular size and weight of the protein were also estimated by dynamic light scattering (DLS; Nonozetasizer, Malvern). The DLS measurements were performed at room temperature, using a protein sample at $0.5 \mathrm{mg} / \mathrm{ml}$ in the same buffer $(20 \mathrm{mM}$ Tris, $150 \mathrm{mM} \mathrm{NaCl}, \mathrm{pH}$ 8.0).

\section{Adsorption assay}

To evaluate the human laforin-CBM substrate affinity and specificity, adsorption assays using starch were carried out. The purified protein samples $(0.25 \mathrm{mg} / \mathrm{ml})$ were centrifuged $(13000 \mathrm{rpm}$, $10 \mathrm{~min}, 4^{\circ} \mathrm{C}$ ) to remove any precipitated protein, and then the protein was mixed with $50 \mathrm{mg}$ of starch (previously washed with $50 \mathrm{mM}$ Tris- $\mathrm{HCl}, 150 \mathrm{mM} \mathrm{NaCl}, \mathrm{pH} 7.4$ buffer) for $1 \mathrm{~h}$ at $4{ }^{\circ} \mathrm{C}$. The mixture was centrifuged ( $13000 \mathrm{rpm}, 10 \mathrm{~min}, 4^{\circ} \mathrm{C}$ ) and the supernatant analyzed by SDS-PAGE. The starch was washed with buffer $(3 \mathrm{X} 0.3 \mathrm{ml})$ and the recombinant $\mathrm{CBM}$ was eluted from starch with a $5 \mathrm{mg} / \mathrm{ml}$ glycogen solution $\left(0.3 \mathrm{ml}\right.$, at $4{ }^{\circ} \mathrm{C}$ for $\left.1 \mathrm{~h}\right)$. The starch was then treated with buffer containing $2 \%$ SDS $\left(0.3 \mathrm{ml}\right.$, at $95{ }^{\circ} \mathrm{C}$ for $5 \mathrm{~min}$ ) in order to analyze the protein that remained adsorbed after glycogen elution.

\section{Results}

\section{Recombinant laforin's CBM expression and purification}

Several strategies were used, attempting the production of the soluble CBM, including periplasmic secretion (pET25b) and fusion with GST - a solubility enhancer tag. Fig. 1 summarizes these approaches and the main results obtained under the conditions tested. Using pET25b, the recombinant protein was not detected in the periplasmic fraction under the conditions tested. The protein was rather expressed in the cytoplasmatic fraction and only in the presence of arginine and CHAPS the purification was possible, using the IMAC system. Nevertheless, native PAGE and DLS analyses indicated protein aggregation and the adsorption assay showed that CBM was not functional (data not shown).

When fused to GST, although soluble, the purified protein was obtained in very low quantities and the CBM did not present starch affinity (data not shown).

Finally, the solubilization and refolding of IBs was the approach leading to the functional CBM; only those results will be presented in this work.

Escherichia coli BL21 star cells transformed with pET29a-CBM vector were grown in $1 \mathrm{~L}$ of $\mathrm{LB}$ medium at $37^{\circ} \mathrm{C}$ and induced with $0.5 \mathrm{mM}$ IPTG for $3 \mathrm{~h}$. Table 2 summarizes the results obtained using the IBs refolding protocol.

Fig. 2 shows the SDS-PAGE analysis of the protein obtained in the insoluble fraction and, after the washing step, recombinant protein showed $68 \%$ purity (Fig. 2C, lane 1 ). The protein has an apparent molecular weight close to the expected $(22 \mathrm{kDa})$ and even under denaturing condition is possible to detect the dimeric form $(44 \mathrm{kDa})$. This result is in agreement with the previously described resistance of laforin to dimer separation, prior to SDS-PAGE [26]. During the refolding step, about $40 \%(62.6 \mathrm{mg})$ of protein had precipitated, but the insoluble material was successfully removed by ultracentrifugation prior to its application onto HiLoad 26/60 Superdex 200 column. The protein detected on the major peak (Fig. 2A), corresponding to the tetramer form of the protein, was loaded onto Mono Q column in order to separate the different protein conformation (Fig. 2B). The purified protein was then analyzed and the results from Superdex 200 10/300 GL column suggested that protein is a dimer. The difference in the oligomerization state between the preparative and analytical Superdex 200 columns resides on the fact that the protein is converted into a dimer in the presence of $150 \mathrm{mM}$ of $\mathrm{NaCl}$, which is not present during preparative purification (data not shown).

Native PAGE analysis and gel filtration chromatography (Superdex 200 10/300 GL equilibrated with $20 \mathrm{mM}$ Tris-HCl, $150 \mathrm{mM}$ $\mathrm{NaCl}$, pH 8.0 buffer) of the highest peak, collected from Mono Q column (Fig. 2B and C, lane 3 ) showed that the refolded protein was not aggregated and exhibits the size corresponding to the dimeric form (44 kDa) and is highly purified (Fig. 3A and B). In addition, the DLS analyses of the sample (in buffer containing $150 \mathrm{mM}$ of $\mathrm{NaCl}$ ) detected a particle with hydrodynamic diameter of $6.5 \mathrm{~nm}$, corresponding to a $44 \mathrm{kDa}$ protein (Fig. 3C) using an empirical calibration developed by Malvern Instruments, thus confirming the dimerization of the isolated protein. The polydispersity of the sample was $0.15 \%$ and the result shown corresponds to an average of 10 measurements.

\section{The ability of the recombinant laforin's CBM to bind carbohydrates}

The functionality of the recombinant protein, i.e., its ability to bind starch, was evaluated using an adsorption assay. Briefly, the protein was incubated with starch and after $1 \mathrm{~h}$, three washing steps were performed with buffer ( $50 \mathrm{mM}$ Tris- $\mathrm{HCl}, 150 \mathrm{mM} \mathrm{NaCl}$, $\mathrm{pH} 7.4$ 


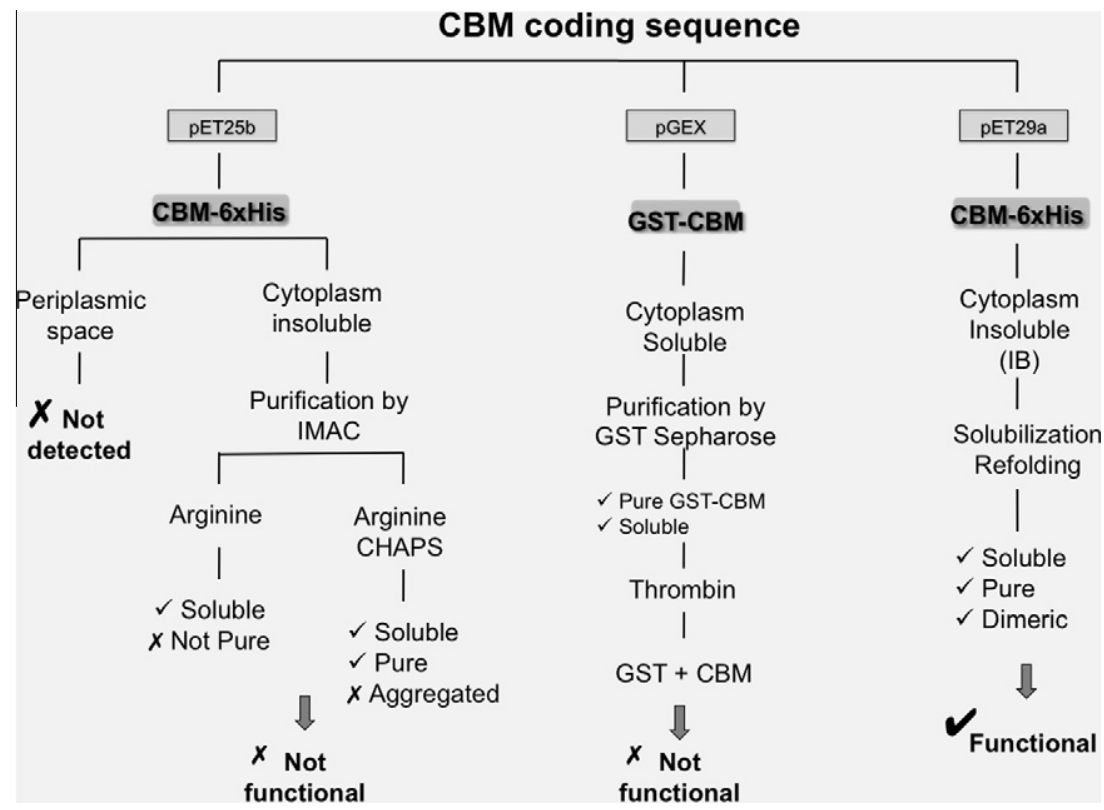

Fig. 1. Summary of strategies and results obtained under the conditions tested.

Table 2

Purification table.

\begin{tabular}{lllrl}
\hline & $\begin{array}{l}\text { Total protein } \\
(\mathrm{mg})\end{array}$ & $\begin{array}{l}\text { Estimated amount } \\
\text { of total CBM }\end{array}$ & Yield (\%) & Purity (\%) \\
\hline Cell extract & 306 & 85.7 & 100 & 28 \\
Refolded protein & 106 & 72.1 & 84 & 68 \\
Applied to Sx200 & 43.4 & 34.7 & 40 & 80 \\
Sx200 \#15-18 & 33 & 29.7 & 35 & 90 \\
Mono Q \#9-14 & 12.8 & 11.5 & 13 & 90 \\
\hline
\end{tabular}

The starting material was $1 \mathrm{~L}$ of $E$. coli expressing CBM-RGD (weight of wet bacteria: $3.74 \mathrm{~g}$ ). Purity was determined by analysis of SDS-PAGE band intensities using the Quantity One software, version 4.6 (BioRad).

buffer). Since no protein has been removed (Fig. 4 - lanes W1 and W2), the elution was performed by incubating the starch moiety with a glycogen $(5 \mathrm{mg} / \mathrm{ml})$ containing buffer. After $1 \mathrm{~h}$, the sample was centrifuged and both the supernatants (E1 and E2) and the pellets (P1 and P2) were analyzed by SDS-PAGE. The results showed that the glycogen was effective in promoting the desorption of CBM, although not completely, since most of the CBM was still present in the pellet fraction (Fig. 4 - lanes P1 and P2).

\section{Discussion}

This is the first report on the expression of the unusual laforinCBM. The production of functional CBM, now achieved, will allow the structural characterization, by crystallography, contributing for the elucidation of mechanistic aspects related to the Lafora disease. Several biomedical applications can be envisioned using this human CBM, such as tag molecule for adsorbing small bioactive peptides to starch-based biomedical materials. The expression of soluble and functional heterologous proteins may be a difficult task, especially for eukaryotic proteins [27]. The heterologous bacterial expression systems remain the most attractive ones due to low cost, high productivity, the well-known genetics and the large number of compatible molecular tools available $[28,29]$. Usually, overexpressed recombinant proteins accumulate either in the cytoplasm and/or in the periplasmic space. However, overexpression of recombinant proteins in bacterial hosts frequently results in IBs, which are amorphous granules of misfolded protein with no biological activity [28,30-32]. The IBs formation frequently occurs, when overexpressing eukaryotic proteins, since posttranslation modification processes are often required for their correct folding and functionality $[27,33,34]$. Commonly, the protein
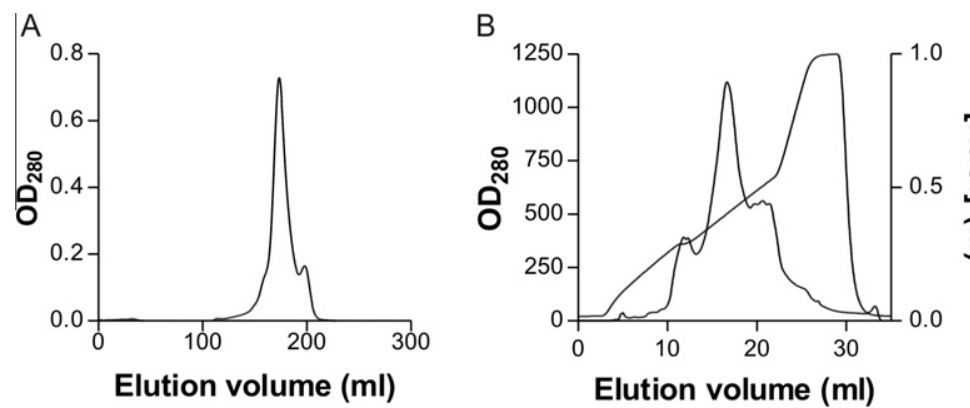

C

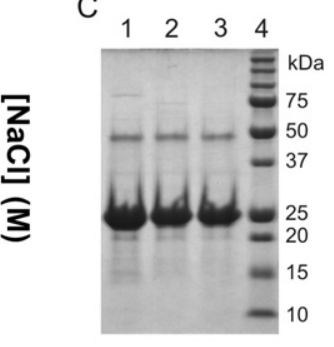

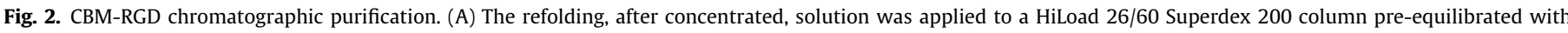

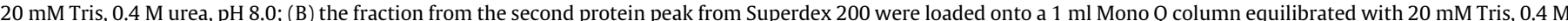

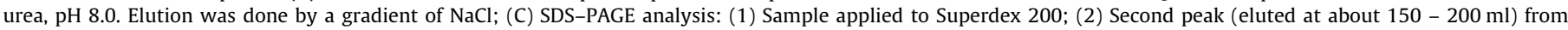
Superdex 200; (3) Highest peak (eluted at about $20 \mathrm{ml}$ ) from Mono Q; (4) Molecular weight Standard. 


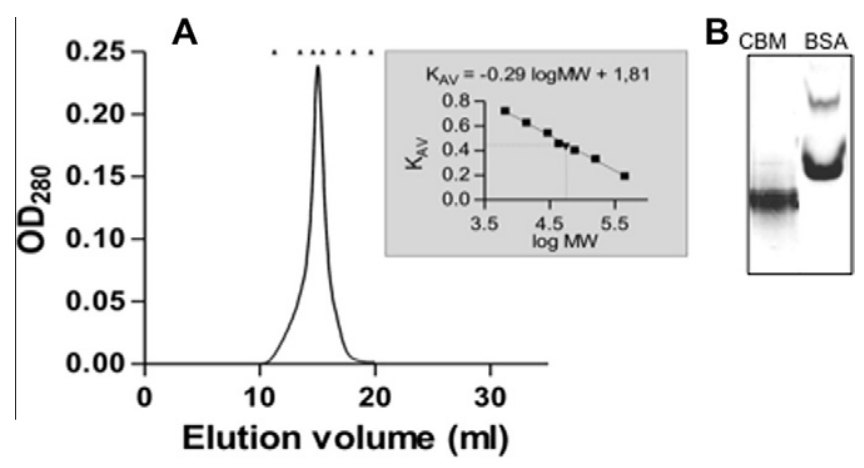

C Size Distribution by Volume

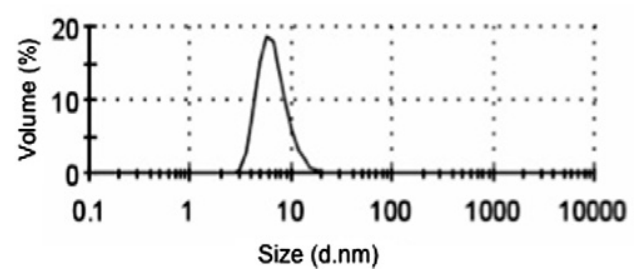

Fig. 3. Analysis of the protein by (A) gel filtration chromatography using a Superdex 200 10/300 GL equilibrated with $20 \mathrm{mM}$ Tris, $150 \mathrm{mM} \mathrm{NaCl}$, pH 8.0 buffer that had been previously calibrated using the GE Healthcare gel filtration molecular weight calibration kit (highlighted box), the triangles indicate the elution volumes of MW markers used for column calibration, (B) native PAGE and (C) DLS analysis of purified protein in buffer containing $150 \mathrm{mM}$ of $\mathrm{NaCl}$. BSA was used as control.

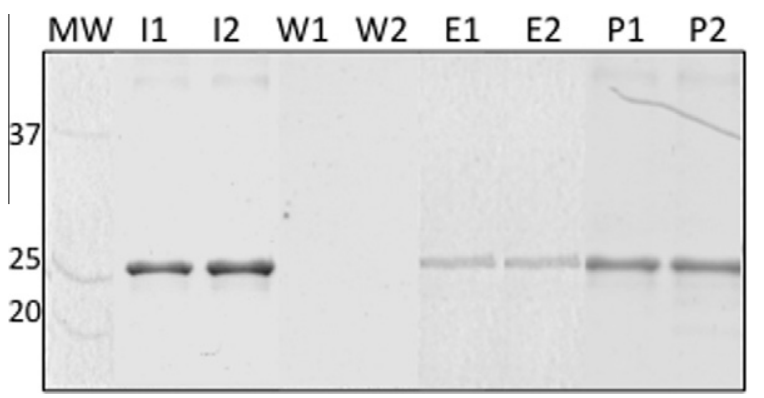

Fig. 4. SDS-PAGE of CBM-RGD adsorption assay to starch. Initial protein (I), washing fraction $(W)$, elution fraction of CBM-RGD with buffer containing glycogen $(E)$ and pellet $(P)$. All steps were done in duplicate and using different protein stock preparations.

expression in IBs is not a first choice for protein production due to poor recovery yields and the customization of the refolding conditions for each target protein. Furthermore, the re-solubilization procedures may affect the integrity of the refolded proteins $[27,28]$. However, in this study, the functional CBM could be obtained only through IBs solubilization and refolding.

Several strategies to enhance the solubility of recombinant proteins are available, among them the use of fusion tags and optimization of the growth and induction conditions [35-37]. In this work, several expression systems were used, attempting to produce soluble CBM, including the fusion with GST-tag, secretion to periplasmic space (where protein was expected to be mostly soluble and correctly processed), different expression hosts, different growth and induction conditions; nevertheless, the recombinant CBM was always obtained in the insoluble fraction or, when soluble, aggregate, lacking starch affinity (data not shown). Moreover, results using chaperone co-expression and Pichia pastoris expression systems (unpublished results) also lead to aggregated recombinant $\mathrm{CBM}$. The full protein laforin, comprising the two modules, has been expressed by other authors as a fusion protein (with GST, 6x-His) in E. coli. This protein showed phosphatase activity on model substrate and affinity for glycogen and starch [1-3,6,38,39]; however, laforin was described as aggregating easily, and indeed it presents different solubility depending on the fused tag [6], with 6xHIS-tagged laforin being less soluble than GST-laforin.

Taken together, the results obtained with the different expression systems point towards the CBM domain being less soluble than the full-length laforin. Indeed, the same expression system effective for the production of the soluble full-length laforin is not suitable for CBM alone.

It is known that, in vivo, the dimerization of laforin, through a CBM-CBM interaction, is essential for its phosphatase activity $[26,40]$. The protein obtained by inclusion bodies solubilization and refolding presented different oligomerization state depending on the presence of salt in the buffer. The DLS analyses of recombinant protein, in buffer containing $150 \mathrm{mM}$ of $\mathrm{NaCl}$, indicated that protein presented a hydrodynamic diameter of $6.5 \mathrm{~nm}$, corresponding to a protein with $44 \mathrm{kDa}$. The DLS analyses confirm the gel filtration chromatography results, suggesting that the protein obtained is the pure CBM dimmer, in buffer containing $150 \mathrm{mM}$ of $\mathrm{NaCl}$. Furthermore, the CBM adsorbed to starch was partially eluted using glycogen, indicating its functionality; however, a considerable amount of CBM remained in the starch-pellet, probably due to the stronger binding of laforin towards starch than glycogen, as previously reported [8] or to the presence of inactive material that precipitated on starch particles.

Further work including assays using CBM-RGD on dextrin hydrogel, as described in a previous work for bacterial CBM [22], and the evaluation in cell adhesion and proliferation on biomaterial; the production of novel recombinant proteins containing the CBM fused to other bioactive peptides; and the study of the three-dimensional structure of the CBM can be considered.

\section{Acknowledgments}

Funding from FCT through POCTI program is acknowledged.

The author S.M. is the recipient of a Post-Doc fellowship from Fundação para a Ciência e a Tecnologia (FCT, Portugal).

\section{References}

[1] S. Ganesh, K.L. Agarwala, K. Ueda, T. Akagi, K. Shoda, T. Usui, T. Hashikawa, H. Osada, A.V. Delgado-Escueta, K. Yamakawa, Laforin, defective in the progressive myoclonus epilepsy of Lafora type, is a dual-specificity phosphatase associated with polyribosomes, Hum. Mol. Genet. 9 (2000) 2251-2261.

[2] J. Wang, J.A. Stuckey, M.J. Wishar, J.E. Dixon, A unique carbohydrate binding domain targets the Lafora disease phosphatase to glycogen, J. Biol. Chem. 277 (2002) 2377-2380

[3] W. Wang, P.J. Roach, Glycogen and related polysaccharides inhibit the laforin dual-specificity protein phosphatase, Biochem. Biophys. Res. Commun. 325 (2004) 726-730.

[4] B.L. Cantarel, P.M. Coutinho, C. Rancurel, T. Bernard, V. Lombard, B. Henrissat, The carbohydrate-active enZymes database (CAZy): an expert resource for glycogenomics, Nucleic Acids Res. 37 (2009) D233-238.

[5] O. Shoseyov, Z. Shani, I. Levy, Carbohydrate binding modules: biochemical properties and novel applications, Microbiol. Mol. Biol. Rev. 70 (2006) 283295.

[6] J.-M. Girard, K.H.D. Lê, F. Lederer, Molecular characterization of laforin, a dualspecificity protein phosphatase implicated in Lafora disease, Biochimie 88 (2006) 1961-1971.

[7] C.A. Worby, M.S. Gentry, J.E. Dixon, Laforin, a dual specificity phosphatase that dephosphorylates complex carbohydrates, J. Biol. Chem. 281 (2006) 3041230418.

[8] E.M. Chan, C.A. Ackerley, H. Lohi, L. Ianzano, M.A. Cortez, P. Shannon, S.W. Scherer, B.A. Minassian, Laforin preferentially binds the neurotoxic starch-like polyglucosans, which form in its absence in progressive myoclonus epilepsy, Hum. Mol. Genet. 13 (2004) 1117-1129.

[9] D.S. Hwang, S.B. Sim, H.J. Cha, Cell adhesion biomaterial based on mussel adhesive protein fused with RGD peptide, Biomaterials 28 (2007) 4039-4046.

[10] W. Dai, W.M. Saltzman, Fibroblast aggregation by suspension with conjugates of poly(ethylene glycol) and RGD, Biotechnol. Bioeng. 50 (1996) 349-356. 
[11] B.K. Mann, J.L. West, Cell adhesion peptides alter smooth muscle cell adhesion, proliferation, migration, and matrix protein synthesis on modified surfaces and in polymer scaffolds, J. Biomed. Mater. Res. 60 (2002) 86-93.

[12] A.J. Schraa, R.J. Kok, A.D. Berendsen, H.E. Moorlag, E.J. Bos, D.K. Meijer, L.F. de Leij, G. Molema, Endothelial cells internalize and degrade RGD-modified proteins developed for tumor vasculature targeting, J. Controlled Release 83 (2002) 241-251.

[13] J. Tan, R.A. Gemeinhart, M. Ma, W.M. Saltzman, Improved cell adhesion and proliferation on synthetic phosphonic acid-containing hydrogels, Biomaterials 26 (2005) 3663-3671.

[14] E. Ruoslahti, M.D. Pierschbacher, New perspectives in cell adhesion: RGD and integrins, Science 238 (1987) 491-497.

[15] J. Li, M. Ding, Q. Fu, H. Tan, X. Xie, Y. Zhong, A novel strategy to graft RGD peptide on biomaterials surfaces for endothelization of small-diameter vascular grafts and tissue engineering blood vessel, J. Mater. Sci. Mater. Med. 19 (2008) 2595-2603.

[16] U. Hersel, C. Dahmen, H. Kessler, RGD modified polymers: biomaterials for stimulated cell adhesion and beyond, Biomaterials 24 (2003) 4385-4415.

[17] S.P. Massia, J. Stark, Immobilized RGD peptides on surface-grafted dextran promote biospecific cell attachment, J. Biomed. Mater. Res. 56 (2001) 390-399.

[18] T.W. Wang, H.C. Wu, Y.C. Huang, J.S. Sun, F.H. Lin, The effect of self-designed bifunctional RGD-containing fusion protein on the behavior of human keratinocytes and dermal fibroblasts, J. Biomed. Mater. Res. B. Appl. Biomater. 79 (2006) 379-387.

[19] A. Wierzba, U. Reichl, R.F. Turner, R.A. Warren, D.G. Kilburn, Adhesion of mammalian cells to a recombinant attachment factor, CBD/RGD, analyzed by image analysis, Biotechnol. Bioeng. 46 (1995) 185-193.

[20] F.K. Andrade, S.M. Moreira, L. Domingues, F.M. Gama, Improving the affinity of fibroblasts for bacterial cellulose using carbohydrate-binding modules fused to RGD, J. Biomed. Mater. Res. A (2009).

[21] C.I. Guerreiro, C.M. Fontes, M. Gama, L. Domingues, Escherichia coli expression and purification of four antimicrobial peptides fused to a family 3 carbohydrate-binding module (CBM) from Clostridium thermocellum, Protein Expr. Purif. 59 (2008) 161-168.

[22] S.M. Moreira, F.K. Andrade, L. Domingues, M. Gama, Development of a strategy to functionalize a dextrin-based hydrogel for animal cell cultures using a starch-binding module fused to RGD sequence, BMC Biotechnol. 8 (2008) 78.

[23] F. Sanger, S. Nicklen, A.R. Coulson, DNA sequencing with chain-terminating inhibitors, Proc. Natl. Acad. Sci. USA 74 (1977) 5463-5467.

[24] G.E. Sroga, J. Dordick, A strategy for in vivo screening of subtilisin E reaction specificity in E Coli periplasm, Biotechnol. Bioeng. 78 (2002) 761-769.

[25] Y.K. Chae, H. Im, Q. Zhao, J.H. Doelling, R.D. Vierstra, J.L. Markley, Prevention of aggregation after refolding by balanced stabilization-destabilization: production of the Arabidopsis thaliana protein APG8a (At4g21980) for NMR structure determination, Protein Expr. Purif. 34 (2004) 280-283.
[26] Y. Liu, Y. Wang, C. Wu, P. Zheng, Dimerization of laforin is required for its optimal phosphatase activity, regulation of GSK3beta phosphorylation, and Wnt signaling, J. Biol. Chem. 281 (2006) 34768-34774.

[27] M.R. Dyson, S.P. Shadbolt, K.J. Vincent, R.L. Perera, J. McCafferty, Production of soluble mammalian proteins in Escherichia coli: identification of protein features that correlate with successful expression, BMC Biotechnol. 4 (2004) 32.

[28] H.P. Sorensen, K.K. Mortensen, Soluble expression of recombinant proteins in the cytoplasm of Escherichia coli, Microb. Cell. Fact. 4 (2005) 1.

[29] K. Terpe, Overview of bacterial expression systems for heterologous protein production: from molecular and biochemical fundamentals to commercial systems, Appl. Microbiol. Biotechnol. 72 (2006) 211-222.

[30] H.P. Sorensen, K.K. Mortensen, Advanced genetic strategies for recombinant protein expression in Escherichia coli, J. Biotechnol. 115 (2005) 113-128.

[31] J.G. Thomas, F. Baneyx, Protein misfolding and inclusion body formation in recombinant Escherichia coli cells overexpressing heat-shock proteins, J. Biol. Chem. 271 (1996) 11141-11147.

[32] A. Villaverde, M.M. Carrio, Protein aggregation in recombinant bacteria: biological role of inclusion bodies, Biotechnol. Lett. 25 (2003) 1385-1395.

[33] D. Esposito, D.K. Chatterjee, Enhancement of soluble protein expression through the use of fusion tags, Curr. Opin. Biotechnol. 17 (2006) 353-358.

[34] S. Jana, J.K. Deb, Strategies for efficient production of heterologous proteins in Escherichia coli, Appl. Microbiol. Biotechnol. 67 (2005) 289-298.

[35] P. Braun, Y. Hu, B. Shen, A. Halleck, M. Koundinya, E. Harlow, J. LaBaer Proteome-scale purification of human proteins from bacteria, Proc. Natl. Acad. Sci. USA 99 (2002) 2654-2659.

[36] M. Hammarstrom, N. Hellgren, S. van Den Berg, H. Berglund, T. Hard, Rapid screening for improved solubility of small human proteins produced as fusion proteins in Escherichia coli, Protein Sci. 11 (2002) 313-321.

[37] Y.P. Shih, W.M. Kung, J.C. Chen, C.H. Yeh, A.H. Wang, T.F. Wang, Highthroughput screening of soluble recombinant proteins, Protein Sci. 11 (2002) 1714-1719.

[38] M.E. Fernandez-Sanchez, O. Criado-Garcia, K.E. Heath, B. Garcia-Fojeda, Medrano-Fernandez, P. Gomez-Garre, P. Sanz, J.M. Serratosa, S. Rodriguez de Cordoba, Laforin, the dual-phosphatase responsible for Lafora disease, interacts with R5 (PTG), a regulatory subunit of protein phosphatase-1 that enhances glycogen accumulation, Hum. Mol. Genet. 12 (2003) 3161-3171.

[39] B.A. Minassian, Lafora's disease: towards a clinical, pathologic, and molecular synthesis, Pediatr. Neurol. 25 (2001) 21-29.

[40] D. Dubey, S. Ganesh, Modulation of functional properties of laforin phosphatase by alternative splicing reveals a novel mechanism for the EPM2A gene in Lafora progressive myoclonus epilepsy, Hum. Mol. Genet. 17 (2008) 3010-3020. 